\title{
Biological Evaluation of Fungal Deteriorated Archeological Wood (Islamic Period) and the Impact of Using Some Fungicides
}

\author{
Rawia F. Gamal, Sohair A. Nasr, Enas A. Hassan, Aliaa M. \\ Attia" and Dalia A. M. Meligy ${ }^{* *}$ \\ Microbiology Dept., Fac. Agric., Ain Shams Univ., Shobra El-Keima ; \\ *Rstoration Dept., Islamic Museum, Cairo and **Center of \\ Research \& Conservation of Antiquities, Cairo, Egypt.
}

\begin{abstract}
7 IGHTY SEVEN fungal isolates were obtained from the surface L of biodeteriorated ceiling wood (No.1803, 1539) from the Islamic museum, Cairo, Egypt (Islamic period). Isolates belonging to eight main genera of fungi were identified, in the following frequencies: Acremonium $2.3 \%$, Alternaria $11.5 \%$, Aspergillus $37.8 \%$, Botryotrichum 2.3\%, Epicoccum 3.5\%, Fusarium 6.9\%, Penicillium 29.9\% and Stemphylium 5.7\%. In a series of trials, cellulase production was maximal for all fungal strains when grown on medium containing 4-6\% of wood straw (at $\mathrm{pH} 4.5-5$ after 1015 days at $30^{\circ} \mathrm{C}$, whereas the maximum production of pectinase was attained on medium containing 6\% wood straw at $\mathrm{pH} 4.5-5$ after 1015 days at $30^{\circ} \mathrm{C}-35^{\circ} \mathrm{C}$.
\end{abstract}

Application of the fungicides dichloroxylenol, paracresol and pentachlorophenol are recommended for use at 1000, 500 and 1000 ppm respectively, based on protection of artificially infected wood. Infected wood lost $40.1 \%$ of its bending strength, but showed increased density and water absorption compared with non infected wood. The lowest bending strength loss was attained with dichloroxylenol( $14.5 \%$ ) followed by wood treatment with pentachlorophenol or paracresol (34.2\%).

Keywords: Wood biodeterioration, Cellulase, Pectinase, Fungicide, Bending strength.

It is well known that wood plays an essential role in man's life and the use of wood has always been considered as a very important part of the history of civilization. The Islamic museum is enriched by having many wooden objects decorated with Islamic ornaments and Arabic writings (Abed-El Razek, 2003). Mourad et al. (2009) noted that during the history of civilizations, advanced wood decay is resulted from exposure to various agents over long periods of time. Blanchette (2000) showed that wooden cultural properties are often degraded by microorganisms when moisture, oxygen and other environmental factors are favorable for microbial growth. Archaeological woods recovered from most environments even those that are extreme typically suffer from some form of biodeterioration. Joao et al. (2003) screened forty-six fungal strains for pectinase production, all of which were positive for pectinase activity in a cup- 
plate assay. Aspergillus giganteus produces polygalacturonase ( $\mathrm{PG})$ at $\mathrm{pH} 5.5-$ 6.5 and $55-60^{\circ} \mathrm{C}$, and polygalacturonases are pectinolytic enzymes that catalyze the hydrolysis of the plant cell-wall pectin backbone (Danielle \& Eleonora, 2010). Harunobu et al. (2000) described three kinds of organo- iodine compounds, 3 iodo-2-propynyl butylcarbamate (IPBC), 1-bromo-3-ethoxy carobonyloxy- 1,2-diiodo-1-propene (BECDIP), and 4-chlorophenyl- 3 iodopropargyl formal (CPIP), which are used as anti fungal agents and wood preservatives against Aspergillus sp., while Marc \& Evelyne (2007) used a mixture of borax, $\mathrm{Na}_{2} \mathrm{~B}_{4} \mathrm{O}_{7} \cdot 10 \mathrm{H}_{2} \mathrm{O}$ and boric acid dissolved in polyethylene glycol (PEG) as a fungicide to treat the Vasa-Sweden's famous warship.

Samples

\section{Materials and Methods}

Deteriorated valuable ceiling wood (No.1803, 1539) were obtained from the Islamic Museum, Cairo, Egypt. (From Islamic period)

\section{Productive medium}

The medium recommended by Ammar et al. (1995) was used for production of cellulase and pectinase, whereas the detection for pectinolytic \& cellulytic isolates was carried out according to Ammar et al. (1998).

\section{Fungicides used}

Three commercially available fungicides namely Dichloroxylenol $\left(\mathrm{C}_{8} \mathrm{H}_{8} \mathrm{Cl}_{2}\right)$, Paracresol $\left(\mathrm{CH}_{3} \mathrm{C}_{6} \mathrm{H}_{4} \mathrm{OH}\right)$ and Pentachlorophenol $\left(\mathrm{C}_{6} \mathrm{Cl}_{5} \mathrm{OH}\right)$ were applied.

\section{Isolation and microbial cultivation}

The biodeteriorated ceiling wood was examined for fungal contents. Their surface was wiped with a sterile wet cotton swab. Then every cotton swab was transferred to an Erlenmeyer conical flask containing $25 \mathrm{ml}$ of sterile tap water and shaken vigorously for $10 \mathrm{~min}$. One $\mathrm{ml}$ of this suspension was transferred to the surface of agar solidified Czapek's medium at $28-30^{\circ} \mathrm{C}$ for 7 days.

\section{Identification}

Identification of the fungal isolates was accomplished based on colonial characters of the pure culture, microscopic characters and by measuring the dimensions of informative characters using a computerized Carl Zeiss microscope Axioplane 2 and the specific program Axio Vision 4.7. Measurements were compared to those available in identification references (Traute et al. 1980 and Alexopoulos et al.,1985).

Examination of the biodeteriorated wood ceiling samples using environmental scanning electron microscopy

The collected samples were investigated using an environmental scanning electron microscope (ESEM) Fei quanta 200 in the Center of Research and Conservation of Antiquities, to determine the major forms of microbial decay.

Egypt. J.Microbiol. 46 (2011) 


\section{Fermentation process}

Fermentation was carried out in $250 \mathrm{ml}$ conical flasks. Each flask contained $100 \mathrm{ml}$ of productive medium (Ammar et al., 1995). The flasks were sterilized at $121^{\circ} \mathrm{C}$ for $15 \mathrm{~min}$ then inoculated with $2 \mathrm{ml}$ of standard inoculum of each isolate. The inoculated flasks were incubated at $28-30^{\circ} \mathrm{C}$ for variable time. At the end of an incubation period, the liquid cultures were centrifuged at $3000 \mathrm{rpm}$ for $15 \mathrm{~min}$. At the end of each incubation period, the supernatant was used to determine the levels of cellulase and pectinase activity according to Ammar et al. (1998).

Effect of environmental conditions on the cellulase and pectinase production by the selected fungi

\section{Wood concentration}

The productive medium (recommended by Ammar et al., 1995) was prepared and supplemented with six different concentrations of wood straw (same type as the wood ceiling, Ficus sycamores and Pinus pinea ) ranging between 2 to $12 \mathrm{gm} / 100 \mathrm{ml}$ liquid medium at 2 gm intervals.

\section{Incubation period}

Incubation was performed for 5, 10, 15, 20 and 25 days for each fungal isolates.

\section{Initial $p H$}

The most potent fungal isolates were inoculated on the productive medium adjusted to $\mathrm{pH}$ values at 0.5 intervals ranging from 3 to 6 .

\section{Incubation temperature}

The most potent fungal isolates were allowed to grow on the productive medium which incubated at different temperature ranged from 20 to $45^{\circ} \mathrm{C}$ with $5^{\circ} \mathrm{C}$ interval.

Determination of minimal inhibitory concentration (MIC) of some fungicides MIC evaluations were carried out according to Brantner et al. (1993).

The impact of using some fungicides on artificially infected wood

Undeteriorated ancient wood was covered with a base layer of animal glue, a carrying layer of calcium carbonate and then with colored layer (elements of coloration layers) to simulate the layers found in biodeteriorated wood samples. It divided into four equal parts then inoculated with $5 \mathrm{ml}$ of mixture sporesuspension of the 18 fungal strains $\left(\sim 0.25 \times 10^{7}\right.$ spores $\left./ \mathrm{ml}\right)$ for incubation at 28$30{ }^{\circ} \mathrm{C}$ under 50-60\% humidity till the fungal growth developed. Optimal MIC of tested fungicide was sprayed on the surface of the infected wood excluding the control region, then incubated as previously mentioned and record any change could be appears. 
Wood properties

Density, water absorption and bending strength of the tested wood, were measured according to Wangaard (1981) and Regis (1999).

\section{Results and Discussion}

\section{Screening and identification}

Eighty seven fungal isolates were obtained from archeological wood, and then subjected to preliminary identification depending on their morphology according to Traute et al. (1980) and Alexopoulos et al. (1985). The incidence, as a percentage of the fungal strains detected is presented in Fig. 1 . Most commonly found were species in the genus Aspergillus $(37.8 \%)$ followed by Penicillium sp. and Alternaria sp. at $29.9 \%$ and $11.5 \%$, respectively. Five genera, Fusarium, Stemphylium, Epicoccum, Acremonium, and Botryotrichum accounted for $6.9 \%, 5.7 \%, 3.5 \%, 2.3 \%$, and $2.3 \%$, respectively of the total fungal isolates. These results are in line with those obtained by Abed-El Hameed (1999) who isolated P. chrysogenun, A. terreus, A. niger, A. flavus, A. versicolor, Mortioella sp. Alternaria alternata and Cladosporium herbarum from wooden coffins in an Egyptian museum .Similarly, Lokma (1999) isolated Aspergillus niger, Asp. flavus, Asp. sulphorous, Asp. sydowii, Asp. versicolor, Alternaria alternata, Cladosporium herbarum, Acremonium sp., Epicoccum sp. and Fusarium solani from some wooden statues in an Egyptian museum.

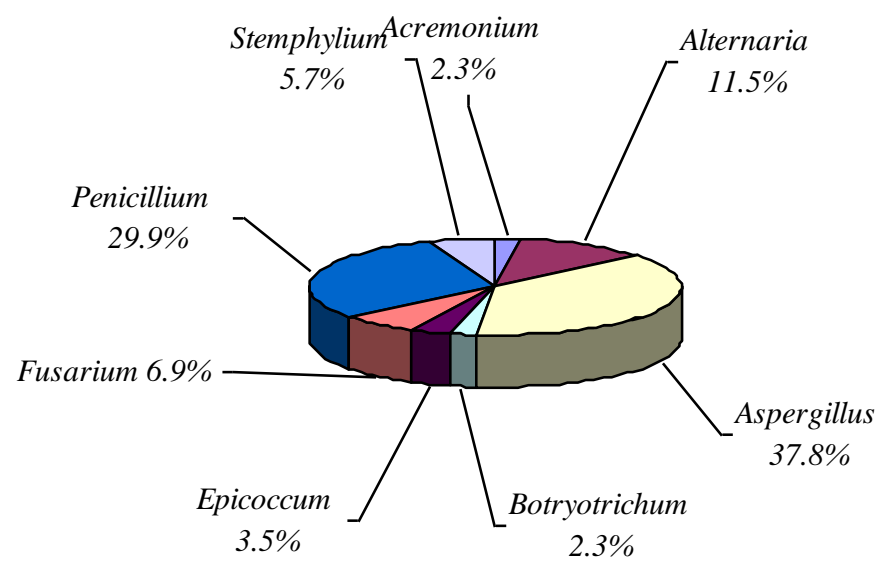

Fig. 1. The incidence percentage of fungal genera isolated from the deteriorated wood No. 1803 and No. 1539 in Islamic museum . 
Investigation of biodeteriorated wood ceiling sample using environmental scanning electron microscopy (ESEM)

Growth characteristics of the fungi on biodeteriorated wood samples and the type of degradative system result in different decay patterns as clearly demonstrated via environmental scanning electron microscopy (Fig.2, A \& B). The mycelial hypha as well as the conidiophores and conidia spores can be seen attached to the plant cell walls. These figures also show decay of the inner layers of xylem cell walls, separation of longitudinal fibers and dense fungal mycelia. Conidia located inside xylem pits and degradation occurring in the margins are visible in Fig 2-C.

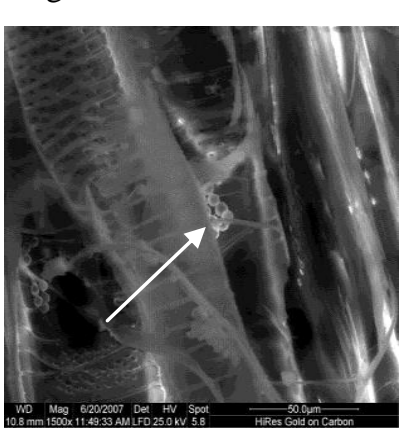

A

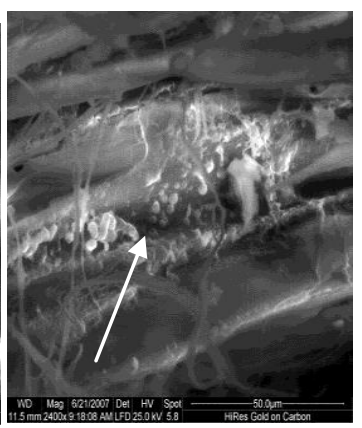

B

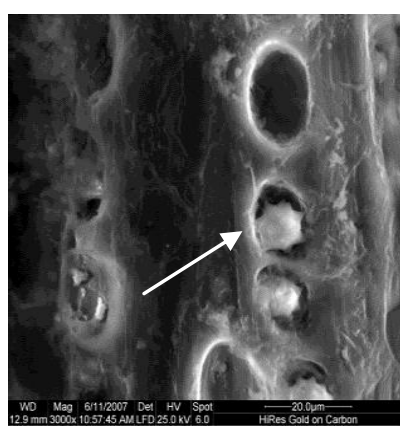

$\mathrm{C}$

Fig. 2. Scanning electron micrograph showing fungal filaments, conidiospores and damage in xylem cell walls.

Capability of the isolated fungal strains for cellulase and pectinase production using cup plate technique

Data recorded in Table 1 indicated that strains of eight fungal species, namely Acremonium strictum, Alternaria geophila, Aspergillus sydowii, Botryotrichum piluliferum, Epicoccum purpurascens, Fusarium mersimoides, Penicillium rubrum and Stemphylium botryosum were the most potent strains for production of cellulose. Strains of Acremonium strictum, Alternaria geophila, Aspergillus sydowii, Botryotrichum piluliferum, Epicoccum purpurascens, Fusarium mersimoides, Penicillium chrysogenum and Stemphylium botryosum were most potent for production of pectinase for each genus .Consequently, these strains were selected for further studies.

Effect of some environmental conditions on the cellulase production by the most potent producers fungal strains

Substrate concentration

The highest yields of cellulase were detected in the presence of $4 \%$ and $6 \%$ wood straw (w.s) (Fig 3). Optimizing wood straw concentration enhanced the enzyme yield to a range between $0.22-0.35$ unit $/ \mathrm{ml}$ after 7 days at $28-30^{\circ} \mathrm{C}$. These results are similar to data obtained by El-Refaie (2005) who found that the maximum cellulase productivity by Chaetomium sp. was attained in the presence of $6 \%$ of wood straw. 
TABLE 1. Capability of the isolated fungal strains for cellulase and pectinase production using cup plate technique.

\begin{tabular}{|l|l|l|l|}
\hline \multirow{2}{*}{ Tested organism } & Cellulases yield & \multirow{2}{*}{ Tested organism } & Pectinase yield \\
\cline { 2 - 2 } & (units/ml) & & \multirow{2}{*}{ (units/ml) } \\
\hline Acremonium strictum & $0.111 \pm 0.016$ & Acremonium strictum & $953 \pm 1.73$ \\
\hline Alternaria alternata & $0.17 \pm 0.011$ & Alternaria alternata & $1901 \pm 0.58$ \\
\hline Alternaria geophila & $0.22 \pm 0.017$ & Alternaria geophila & $2394 \pm 4.62$ \\
\hline Alternaria tenuissima & $0.17 \pm 0.006$ & Alternara tenuissima & $953 \pm 1.73$ \\
\hline Aspergillus carneus & $0.44 \pm 0.23$ & Aspergillus carneus & $601 \pm 0.58$ \\
\hline Aspergillus niger & $0.27 \pm 0.017$ & Aspergillus niger & $477 \pm 13.3$ \\
\hline Aspergillus sydowii & $0.55 \pm 0.029$ & Aspergillus sydowii & $953 \pm 1.73$ \\
\hline Aspergillus terreus & $0.111 \pm 0.011$ & Aspergillus terrus & $315 \pm 2.88$ \\
\hline Aspergillus versicolor & $0.111 \pm 0.0$ & Aspergillus versicolor & $315 \pm 2.31$ \\
\hline Botryotrichum piluliferum & $0.35 \pm 0.029$ & Botryotrichum piluliferum & $601 \pm 1.73$ \\
\hline Epicoccum purpurascens & $0.27 \pm 0.017$ & Epicoccum purpurascens & $301 \pm 0.0$ \\
\hline Fusarium mersimoides & $0.44 \pm 0.023$ & Fusarium mersimoides & $601 \pm 2.31$ \\
\hline Penicillium chrysogenum & $0.35 \pm 0.006$ & Penicilium chrysogenum & $1200 \pm 5.77$ \\
\hline Penicillium islandicum & $0.111 \pm 0.017$ & Penicilium islandicum & $315 \pm 5.77$ \\
\hline Penicillium lanosum & $0.14 \pm 0.023$ & Penicilium lanosum & $601 \pm 5.77$ \\
\hline Penicillium rubrum & $0.44 \pm 0.0$ & Penicilium rubrum & $315 \pm 2.88$ \\
\hline Penicillium rugulosum & $0.22 \pm 0.017$ & Penicilium rugulosum & $953 \pm 1.73$ \\
\hline Stemphylium botryosum & $0.27 \pm 0.017$ & Stemphylium botryosum & $315 \pm 2.88$ \\
\hline Results are expressed a & &
\end{tabular}

Results are expressed as the means \pm standard error of three replicates.

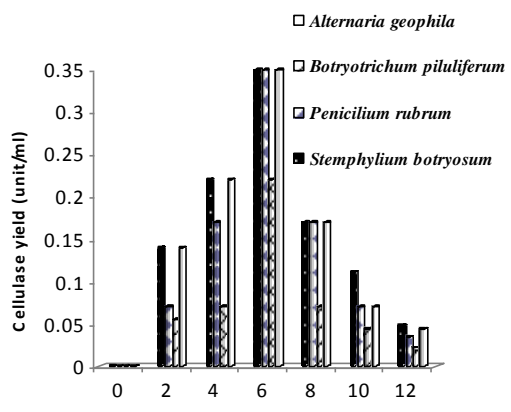

w.s. concentration (\%)

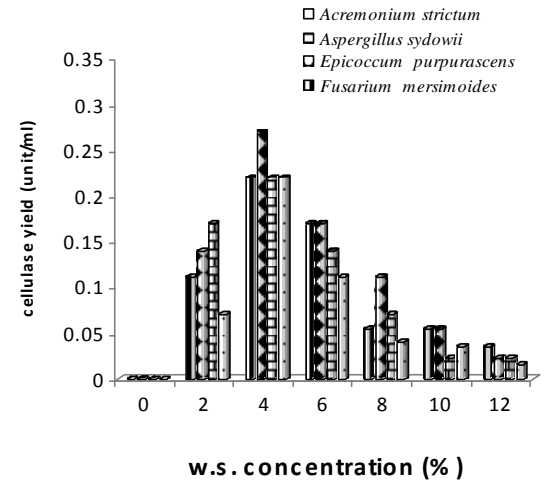

(B)

Fig. 3. Effect of different wood straw concentrations on cellulase production by the most potent fungal strains (A \&B ) for 7 days at $28-30{ }^{\circ} \mathrm{C}$

\section{Incubation period}

Strains of Acremonium strictum, Aspergillus sydowii, Epicoccum purpurascens and Fusarium mersimoides attained the highest yield of cellulase which ranged between $0.17-0.27 \mathrm{unit} / \mathrm{ml}$ in the presence of $4 \%$ wood straw (w.s.) at $28-30^{\circ} \mathrm{C}$ for 10 day Penicilliun rubrum gave the lowest activity in the presence of 65 wood strar (w.s.) after 15 day (Fig. 4-8 ). These results are in agreement with El-Refaie (2005) who (Fig. 4-A). Alternaria geophila was precede as a cellulase producer whereas found that Chaetomium gloosbum gives the highest yield of cellulase enzyme

Egypt. J.Microbiol. 46 (2011) 
after 15 days while, Immanuel \& Akila (2007) found the highest yield of the enzyme after 5 days of growth by Aspergillus niger \& Aspergillus fumigatus.
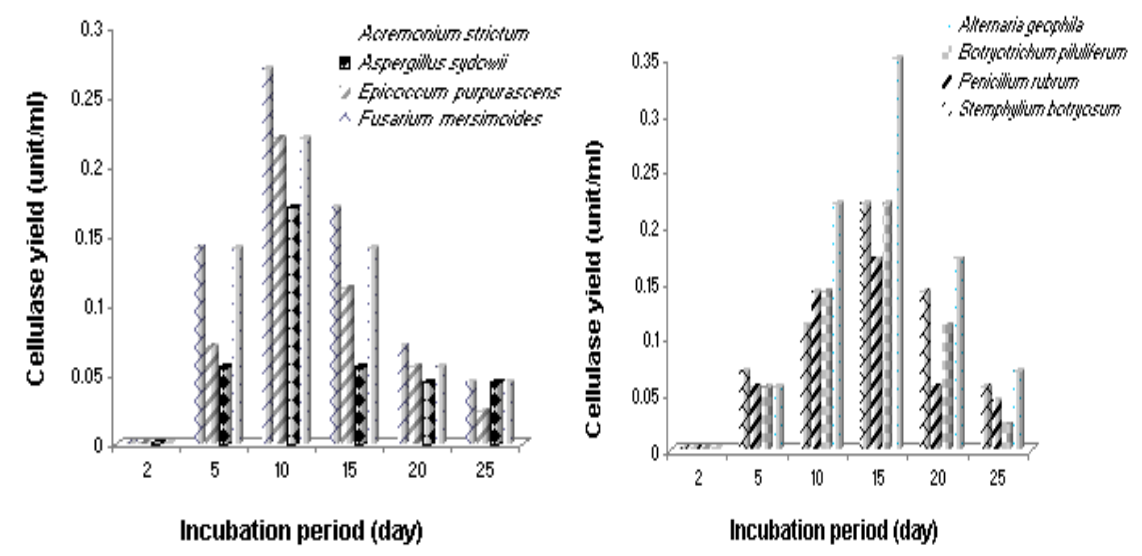

Fig. 4. Effect of different incubation periods on cellulase production by the selected fungal strains on medium containing $4 \%$ w.s. $/ 28-30^{\circ} \mathrm{C}$ (A) \& $6 \%$ w.s. $/ 28-30^{\circ} \mathrm{C}$ (B) .

Initial $\mathrm{pH}$ value

All the tested fungi gave the highest yield of cellulase at $\mathrm{pH} 4.5$ on medium containing $4 \%$ wood straw (w.s.) after 10 day (Fig. 5-A). These results match those of Immanuel \& Akila (2007) who also found that Aspergillus sp. gave the highest yield of enzyme at $\mathrm{pH}$ 4.5. From Fig (5-B) it can be concluded that the optimum $\mathrm{pH}$ value capable of promoting cellulase biosynthesis by all the tested fungal strains was 5 on medium containing $6 \%$ wood straw (w.s.) after 15 days at $28-30^{\circ} \mathrm{C}$. These results are in line with Coral et al. (2002) who found an optimum of $\mathrm{pH} 5$ for Alternaria sp.

\section{Incubation temperature}

The optimal incubation temperature was $30^{\circ} \mathrm{C}$ either in the presence of $4 \%$ wood straw (w.s.) at $\mathrm{pH} 4.5$ for 10 days or $6 \%$ wood straw (w.s.) at $\mathrm{pH} 5$ for 15 days Fig (6. A\&B). These results are in line with El-Hawary et al. (2001) who found that the highest enzyme activities were obtained from Aspergillus niger at $30^{\circ} \mathrm{C}$. On the contrary, Danielle \& Eleonora (2010) found that optimal temperature for activity of cellulase was ranged from $50^{\circ} \mathrm{C}$ to $55^{\circ} \mathrm{C}$ by Aspergillus giganteus.

Effect of some environmental conditions on pectinase production by the most potent fungal strains

Substrate concentration

The fungal strains were able to produce the highest yield of pectinase when grown in media containing $6 \%$ wood straw (w.s.) . The maximum was 5002 unit $/ \mathrm{ml}$ attained by Aspergillus sydowii while the lowest at $1901 \mathrm{unit} / \mathrm{ml}$ was detected for 
Botryotrichum piluliferum and Penicillium chrysogenum after 7days (Fig 7A\&B). These results differ from those of El-Refaie (2005) who found that the maximum pectinase productivity by Chaetomium sp. was attained in the presence of $4 \%$ of wood straw.

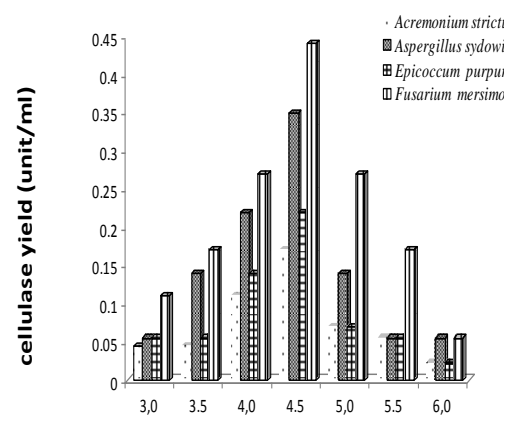

$\mathrm{pH}$ values

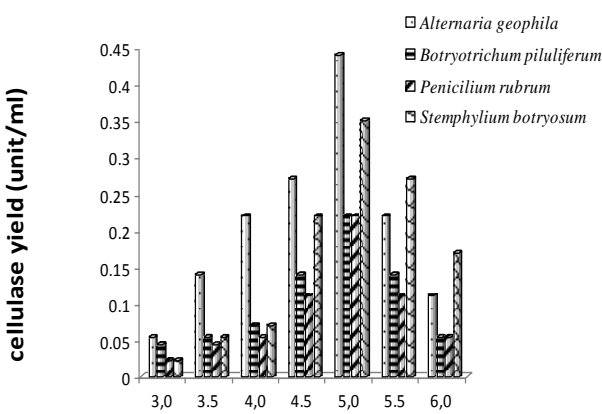

$\mathrm{pH}$ values

A

B

Fig. 5. Effect of different $\mathrm{pH}$ values on cellulase production by the selected fungal strains on medium containing $4 \%$ w.s. for 10 days $/ 28-30^{\circ} \mathrm{C}$ (A) \& $6 \%$ w.s. for 15 days $/ 28-30^{\circ} \mathrm{C}(\mathrm{B})$.
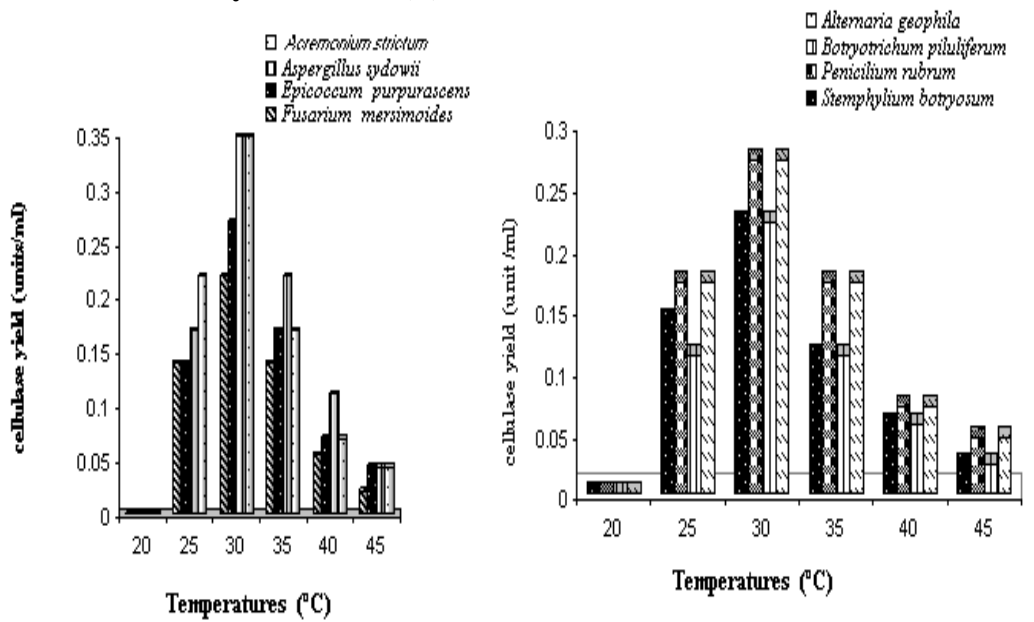

Fig. 6. Effect of different incubation temperatures on cellulase production by the selected fungal strains on medium containing $4 \%$ w.s. at pH 4.5 for 10 days (A) \& $6 \%$ w.s. at pH 5 for 15 days (B). 


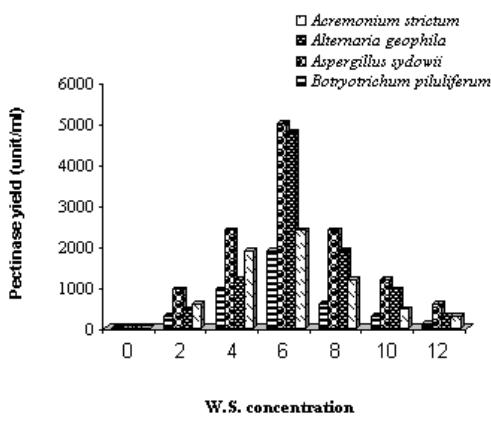

A

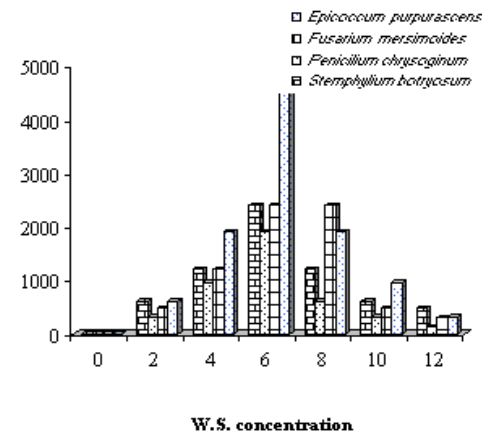

B

Fig. 7. Effect of different wood straw concentrations on pectinase production by the most potent fungal strains $(\mathrm{A} \& \mathrm{~B})$ for 7 days at $28-30{ }^{\circ} \mathrm{C}$

\section{Incubation period}

The maximum pectinase yields of 1901, 1901, 2394, 4777 unit/ml were attained by Acremonium strictum, Epicoccum, purpurascens, Fusarium mersimoides and Stemphylium botryosum respectively after 10 days. The fungal strains which produced the highest enzyme after 15 days were Alternaria geophila, Aspergillus sydowii, Botryotrichum piluliferum and Penicillium chrysogenum (Fig. 8- A\&B). These results are in agreement with El-Refaie (2005) who found that the Alternaria geophila produced the highest yield of pectinase after 15 days.

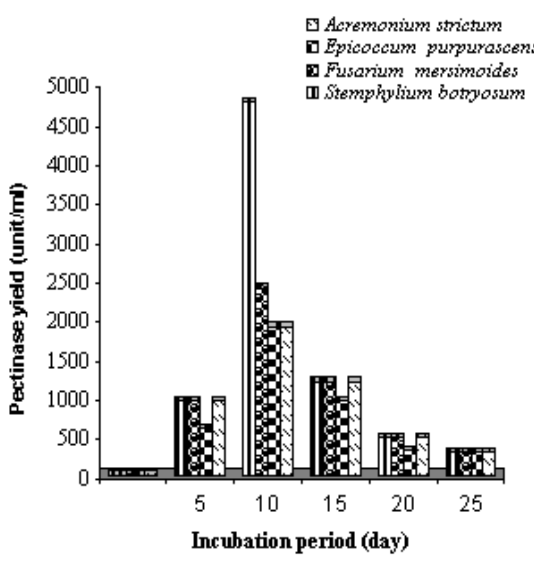

A

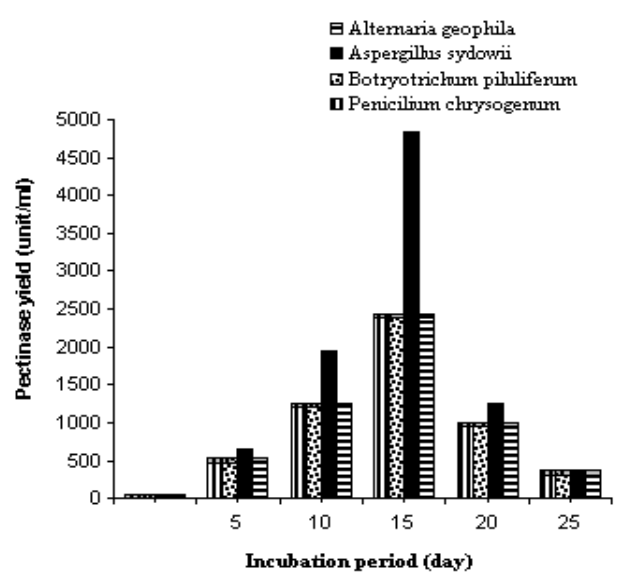

B

Fig. 8. Effect of different incubation periods on pectinase production by the selected fungal strains $(\mathrm{A}, \mathrm{B})$ on medium containing $6 \%$ w.s. at $28-30^{\circ} \mathrm{C}$.

Egypt. J.Microbiol. 46 (2011) 
Initial $\mathrm{pH}$ value

The optimal $\mathrm{pH}$ value capable of promoting enzyme biosynthesis by Acremonium strictum, Epicoccum purpurascens, Fusarium mersimoides and Stemphylium botryosum was found to be $\mathrm{pH} 4.5$ for 10 days. The other strains (Alternaria geophila, Aspergillus sydowii, Botryotrichum piluliferum and Penicillium chrysogenum) gave the maximum yield of enzyme at pH 5 after 15 days (Fig 9- A \& B). These results are in agreement with Yogesh et al.(2009) who found that Aspergillus niger produced high pectinase at pH $3.8-5$.

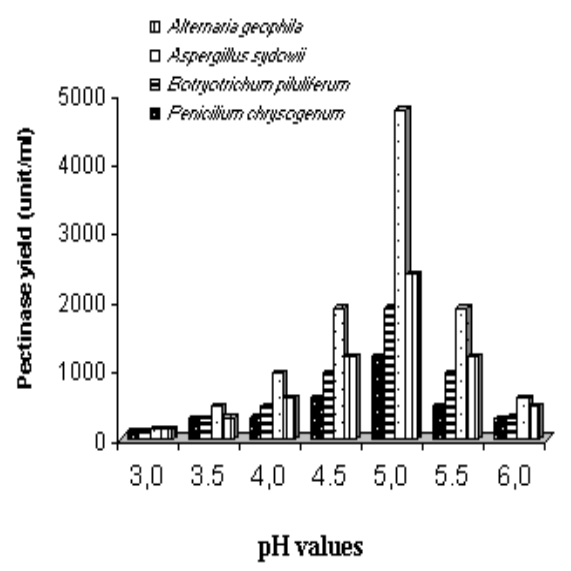

A

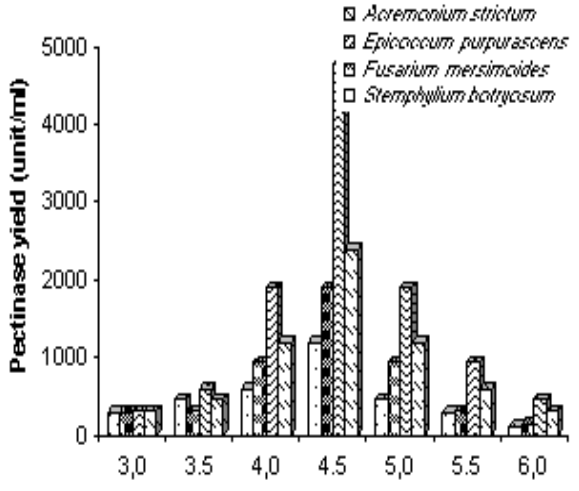

$\mathrm{pH}$ values

B

Fig. 9. Effect of different $\mathrm{pH}$ values on pectinase production by the selected fungal strains on medium containing $6 \%$ w.s. $/ 15$ days at $28-30^{\circ} \mathrm{C}$ (A) \& $6 \%$ w.s. $/$ 10 days at $28-30^{\circ} \mathrm{C}(\mathrm{B})$.

Incubation temperature

Results revealed that $30^{\circ} \mathrm{C}$ at $\mathrm{pH} 4.5$ was the optimal temperature for pectinase produced by Acremonium strictum and Epicoccum purpurascens whereas it was $35^{\circ} \mathrm{C}$ for Fusarium mersimoides and Stemphylium botryosum at the same $\mathrm{pH}$ and 10 days incubation period. Pectinase production by Alternaria geophila, Aspergillus sydowii, Botryotrichum piluliferum and Penicillium chrysogenum was maximized at $30^{\circ} \mathrm{C} \& 35^{\circ} \mathrm{C}$ (Fig. 10- A\&B). Yogesh et al (2009) also found that $A$. niger gave high activity of pectinase at $30^{\circ} \mathrm{C}$.

The proper concentration of some fungicides against the fungal strains

Three compounds namely dichloroxylenol (125- $2000 \mathrm{ppm})$, paracresol $(125$ - $2000 \mathrm{ppm})$ and pentachlorophenol $(250-2000 \mathrm{ppm})$ were tested for effectiveness as fungicides against 18 fungal strains. The optimal concentration for use of each as a fungicide is recorded in Table 2. Applications of dichloroxylenol, paracresol and pentachlorophenol at 1000, 500 and $1000 \mathrm{ppm}$, respectively, killed all of the tested fungi. Shash \& Arya (1999) and Regis (1999) stated that periodical fungal spraying of pentachlorophenol was useful in preventing fungal attack as it penetrates deeply.

Egypt. J.Microbiol. 46 (2011) 
BIOLOGICAL EVALUATION OF FUNGAL DETERIORATED...

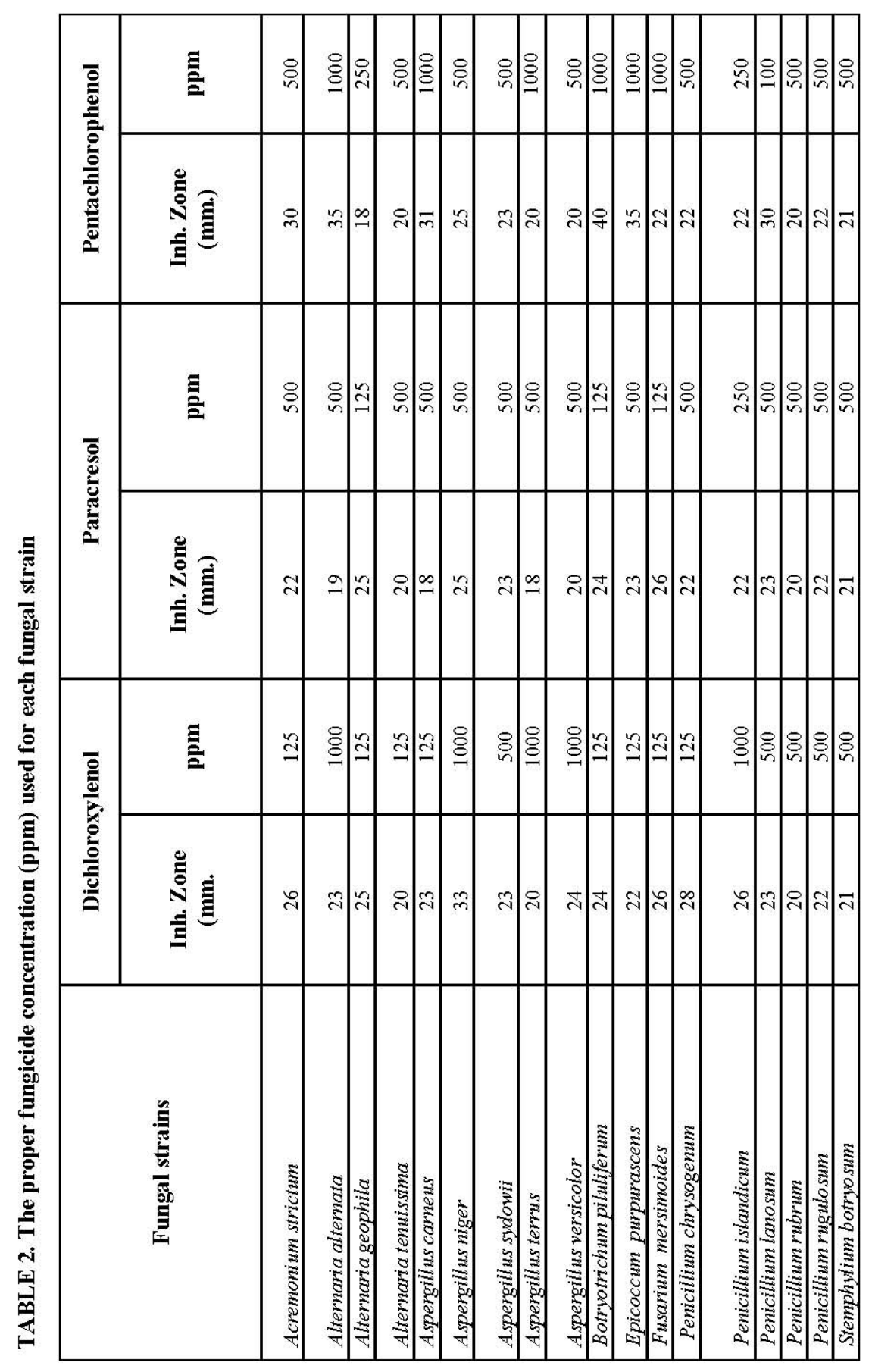

Egypt. J.Microbiol. 46 (2011) 


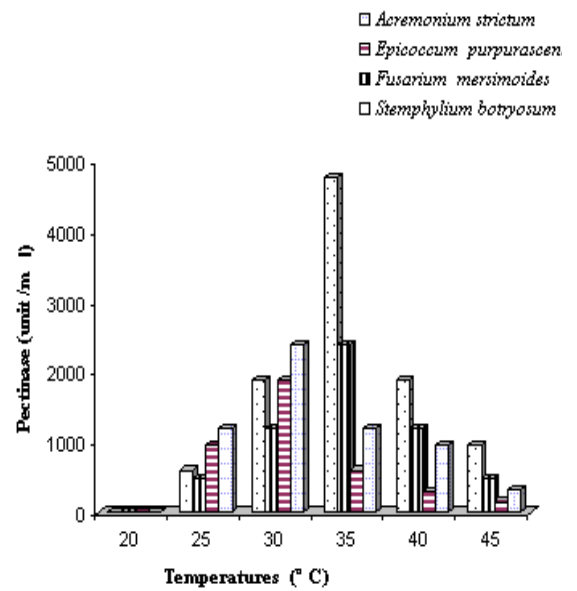

A

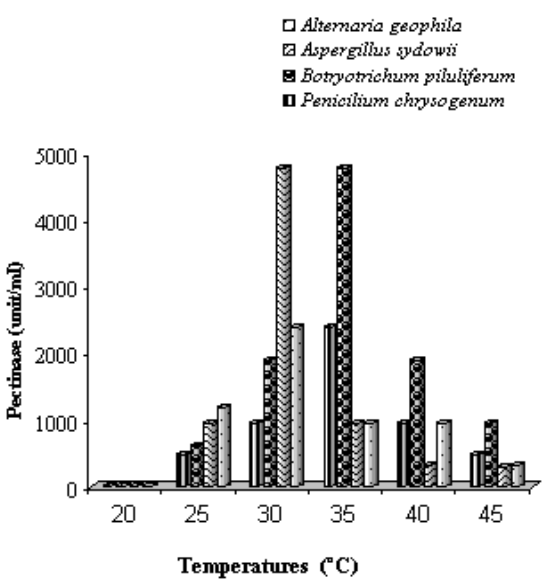

B

Fig. 10. Effect of different incubation temperatures on pectinase production by selected fungal strains on medium containing $6 \%$ w.s. at pH 4.5 for 10 days $(\mathrm{A}) \& 6 \%$ w.s. at $\mathrm{pH} 5$ for 15 days $(\mathrm{B})$.

Impact of some fungicides on the artificial infected wood

Figures 11-13 summarize results of the procedural steps which carried out on artificially infected wood. No fungal growth could be detected on the surface of inoculated wood samples till $\sim 8$ months after fungicides treatment at $28^{\circ}-30^{\circ} \mathrm{C}$ under 50-60\% humidity when compared to the untreated part (Fig. 13)

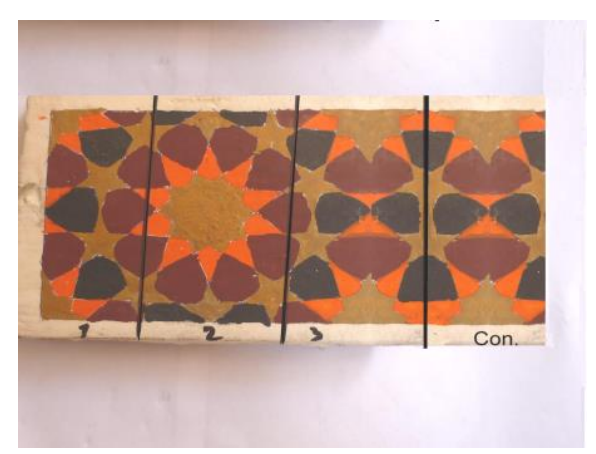

Fig. 11. Wood samples divided into four parts and sprayed with a mixed spore suspension (18 fungal strains) .

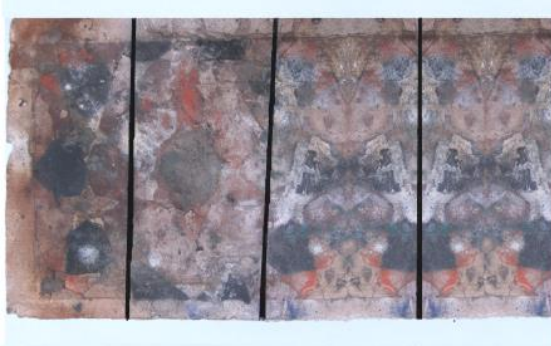

2

Control

Fig. 12. Fungal growth appears on the surface after 60 days at room temperature (before fungicides treated). 


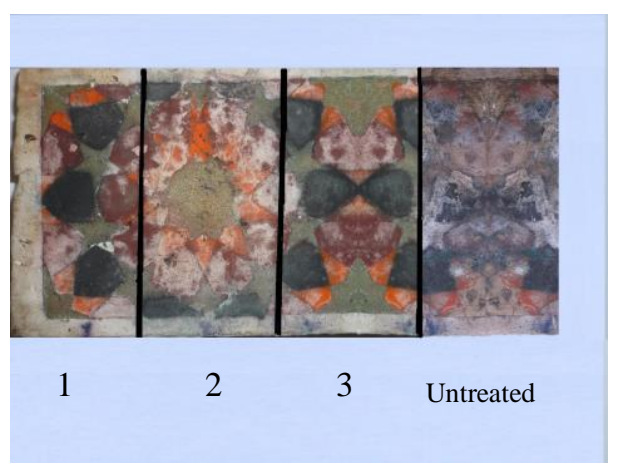

Fig. 13. The infected inoculated wood after 8 months of fungicides treated .

\section{Wood properties}

Data presented in Table 3 recorded standard physical properties of wood, including density, water absorption and bending strength measured before and after infection and with or without pretreatment with dichloroxylenol, pentachlorophenol or paracresol. The infected wood resulted in a loss of $40.1 \%$ of bending strength. Higher density and water absorpation were detected as compared with non-infected wood. Regarding the effect of wood treatment the data indicated that the lowest bending strength loss was attained with dichloroxylenol $(14.5 \%)$ followed by wood treatment with pentachlorophenol or paracresol (34.2\%). From the previous data, it could be concluded that the wood treatment with di-chloroxylenol was best in improving the physical properties of the infected wood.

TABLE 3. Physical properties of wood sample (before and after infected and treated with fungicides).

\begin{tabular}{|c|c|c|c|c|c|}
\hline \multirow{2}{*}{ Test } & \multirow{2}{*}{$\begin{array}{c}\text { Non } \\
\text { infected } \\
\text { wood }\end{array}$} & $\begin{array}{c}\text { Infected } \\
\text { wood }\end{array}$ & $\begin{array}{c}\text { With } \\
\text { dichlorox- } \\
\text { ylenol }\end{array}$ & $\begin{array}{c}\text { With } \\
\text { pentachloro- } \\
\text { phynol }\end{array}$ & $\begin{array}{c}\text { With } \\
\text { Paracresol }\end{array}$ \\
\hline $\begin{array}{c}\text { Bending strength } \\
\text { (MPa) (megapascal) }\end{array}$ & 15.2 & 9.1 & 13 & 10 & 10 \\
\hline Water absorption $(\%)$ & 65.1 & 68.8 & 65 & 67 & 67 \\
\hline Density $\left(\mathrm{gm} / \mathrm{cm}^{3}\right)$ & 0.35 & 0.40 & 0.37 & 0.40 & 0.40 \\
\hline
\end{tabular}

\section{References}

Abed-EL Hameed, Aliaa M. (1999) Studies of the treatment and conservation of polychrome wooden coffins and practical application in this field. Ph.D. Thesis, Dept. of Conservation; Fac. of Archaeology, Cairo Univ., Cairo, Egypt.

Abed-El Razek, A. (2003) "The Islamic Arts in Ayoub Mamloki Period." pp 71-88, Faculty of Arts, Ain Shames University, EL-Hariry Publ., Cairo, Egypt (in Arbic) . 
Alexopoulos, C.J., Mims, C.W. and Balockwell, M. (1985) "Introductory Mycology". $4^{\text {th }}$ ed. pp. 215-250. New York, Chichester Brisbane Tornto Singapore.

Ammar, M.S., Loboudy, S.S. and Afifi, M.M. (1995) A new method for the estimation of fungal pectinase (s) using the pecting clearing zone (P.C.Z) and its application in food Industries. Al-Azher Bull. Sic. 6 (1), 325-339.

Ammar, M.S., Loboudy, S.S, Azab, M.S. and Afifi, M.M. (1998) Inductive Biosynthesis of a thermophilic ST-pectinase by Aspergillus niger, TAT, pollutant fungus TUT Ankh Amon Tomb allowed to attack Solanum tuberosum (ST) peels under solid state fermentation (S.S.F.) in Baxter Botles Egypt. J. Biotech. 4, 69-83.

Blanchette, R.A. (2000) A review of microbial deterioration found in archaeological wood from different environments. International Biodeterioration and Biodegradation, 46, $189-204$.

Brantner, A., Peiffer, K.P. and Grein, E. (1993) Antibacterial assays of the pharmacopoeias: diffusion tests of natural substances and evaluation. J. Planta Med. 59, 675-681

Coral, G., Arikan, B., Unaldi, M.N. and Guvenmens, H. (2002) Some properties of crude carboxymethyl cellulase of Aspergillus niger and Alternaria sp. J. Biol. 26, 209-213.

Danielle, B.P. and Eleonora, C.C. (2010) purification and characterization of the exopolygalacturonase and cellulase produced by Aspergillus giganteus in submerged cultures. J. Industrial Microbiology \& Biotechnology, 37(6), 567-573.

El-Hawary, F.I., Mostafa, Y.S. and laszol, E. (2001) Cellulase production and conversation of rice straw to lactic acid by simultaneous saccharification and fermentation. Acta Alimentaria. Budapest, 30 (3), 281-295

El-Refaie, A. A. (2005) Biotechnological application of Egyptian antiquities microflora in the biosynthesis of digestive enzymes under solid state fermentation conditions. pp. 114-158, Ph. D. Thesis, Dept. Microbiology, Faculty of Sciences, Al-Azhar University, Cairo, Egypt.

Harunobu, N., Matsunaga, I., Miyano, N. and Kitagawa, M. (2000) Deterioration of organoiodine antimicrobial in gradients in commercially available antimicrobial deodorant agents. Osaka Prefectural Institute of Public Health Japan. 537.

Immanuel, G. and Akila, C.M. (2007) Production and partial purification of cellulase by Aspergillus niger and A. fumigates fermented in Coir waste and Sawdust. Journal of Microbiology, 3 (1), 40-50.

Joao, V.B., Souza, E., Silvia, S., Marica, S., Maria, L.S. and Teixeira, F.S. (2003) Screening of fungal strains for pectinolytic activity endopoly-galacturonanse production by Peacilomyces clavisporus. Process Biochemistry, 39, 455-458

Lokma, N. (1999) Studies of the treatment and conservation of dry wood applied and the select wooden statues from the Egyptian Museum, Ph.D. Thesis, Dept. of Conservation. Fac. of Archeology, Cairo Univ., Cairo, Egypt . 
Marc, A. and Evelyne, D.C. (2007) the surface of cultural heritage artefacts: physicochemical investigations for their knowledge and their conservation. The Royal Society of Chemistry, 36, 1605-1621

Mourad, Z., Dounia, M., Mohammed, M., Mohammed, I., Abdellatif, H., Mohamed, E. and Saad, I.K. (2009) Cellulolytic potential of fungi in wood degradation from an old house at the Medina of Fez. Annals of Microbiology, 59 (4), 699-704

Regis, B. Miller (1999) "Wood Hand Book Wood as an Engineering”. Forest Service, Forest Products Laboratory, pp. 463-466

Shash, N.R. and Arya, A. (1999) Problems of biodeterioration a case study, $3^{\text {rd }}$ Int. Symp. on Restoration and Conservation of Monuments, Hyderabad, India. pp. 155-158.

Traute, H.A., Donsch, K.H. and Gams, W. (1980) Compendium of Soil Fungi. Academic Press. A subsidiary of Harcourt Brace Jovanovich, Publishers, London, New York. pp. 550-609

Wangaard, F.F. (1981) "Wood: Its Structure and Properties" Vol.1 EMMSE, Pennesylvania, USA, pp. 465.

Yogesh, K., Vamsi, K., Amol, B., Nikhil, G., Soham, T., Prasad, P., Girish, G., Mayank, G., Amol, J., Adarsh, M. and Joshi, B. (2009) study of pectinase production in submerged fermentation using different strains of Aspergillus niger. International Journal of Microbiology Research, 1(2), 13-17 


\section{التقييم الحيوي لتدهور الأخثاب الأثرية (عصر اسلامي) بالفطريات وتأثير أستخدام بعض المبيدات الفطرية} عطية* ف دأليا جمال ، محمد ملير احمد نصر ، ايناس عبد التواب حسن ، علياء محمد

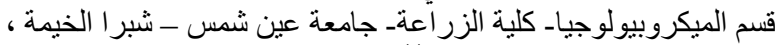

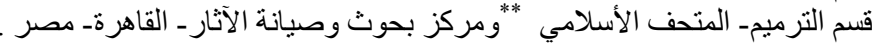

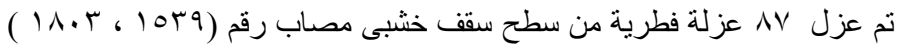

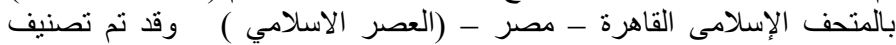
العزلات الفطرية إلى ثمانية أجناس هى: Acremonium \& (2.3\%) Alternaria (11.5\%) \& (37.8\%) Aspergillus \& (2.3\%) Botryotrichum \& (3.5\%) Epicoccum \& (6.9\%) Fusarium \& (29.9\%) Penicillium and (5.7\%) Stemphylium

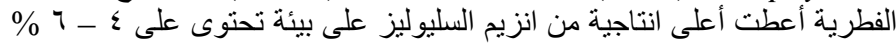

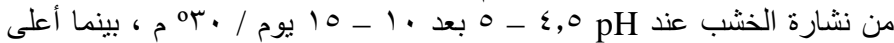

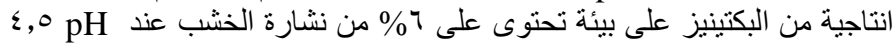

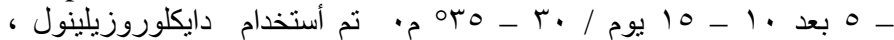

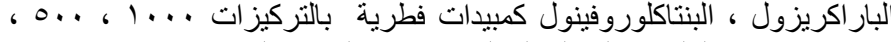

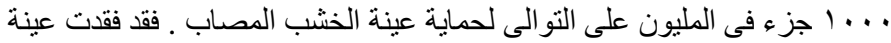

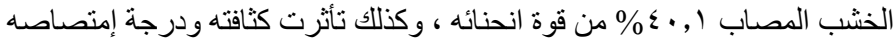

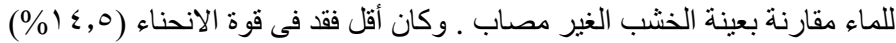

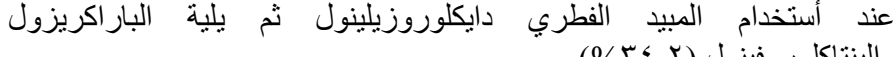
و البنتاكلوروفينول (r, « r\%). 